\title{
PENGEMBANGAN MEDIA GAME EDUKASI BERBASIS ANDROID PADA TOPIK BILANGAN BULAT KELAS VI SEKOLAH DASAR
}

\author{
Karseno ${ }^{1}$, Sariyasa ${ }^{2}$, I.G. Astawan ${ }^{3}$ \\ ${ }^{123}$ Program Studi Pendidikan Dasar \\ Universitas Pendidikan Ganesha \\ Singaraja, Indonesia \\ e-mail: karseno@undiksha.ac.id ${ }^{1}$, sariyasa@undiksha.ac.id ${ }^{2}$, \\ astawan@undiksha.ac.id $^{3}$
}

\begin{abstract}
Abstrak
Pembelajaran daring pada masa pandemi ini membawa dampak rendahnya hasil belajar matematika siswa yang disebabkan oleh kesulitan guru dalam menjelaskan materi dan kurangnya media pembelajaran. Penelitian pengembangan ini bertujuan untuk menghasilkan media game edukasi berbasis android pada topik bilangan bulat kelas VI Sekolah Dasar yang valid dan praktis. Penelitian ini dilaksanakan dengan menggunakan model ADDIE (Analysis, Design, Development, Implementation, Evaluation). Game edukasi yang dihasilkan dalam pengembangan ini berjudul "Ayo Selamatkan Bumi". Game ini berisi materi mata pelajaran matematika topik bilangan bulat. Metode pengumpulan data yang digunakan adalah kuesioner dengan melibatkan ahli, guru, dan siswa. Uji validitas game edukasi dilakukan dua orang ahli materi, dua orang ahli media pembelajaran, dan dua praktisi. Uji coba terbatas dilakukan secara daring pada 9 siswa kelas VI SD Negeri 2 Banjar Anyar untuk mengetahui tingkat kepraktisan game edukasi yang dikembangkan. Data yang diperoleh dari uji validitas dan uji coba terbatas dianalisis menggunakan rumus mean untuk mengetahui rata-rata skor. Hasil uji validitas dari game edukasi ini diperoleh skor ahli materi 4,85 dan ahli media 4,88 yang berarti sangat baik. Sedangkan untuk kepraktisan, diperoleh skor 4,5 dengan kriteria sangat baik. Dari hasil tersebut dapat ditarik kesimpulan bahwa game edukasi ini dapat digunakan sebagai media pembelajaran matematika topik bilangan bulat kelas VI Sekolah Dasar.
\end{abstract}

Kata kunci: Android; Bilangan; Edukasi; Game; Matematika

\begin{abstract}
Online learning during this pandemic has an impact on students' low mathematics learning outcomes caused by the difficulty of teachers in explaining the material and the lack of learning media. This development research aimed to develop a valid and practical educational game media Androidbased on the integers topic for grade VI Elementary School. This research was carried out using the ADDIE model (Analysis, Design, Development, Implementation, Evaluation). The educational game entitled "Ayo Selamatkan Bumi". This game contained math subject on the topic of integers. The data collection method used a questionnaire involving experts, teachers, and students. The validity test of educational games was conducted by two material experts, two learning media experts, and two practitioners. A limited trial was conducted online at 9 grade VI students of SD Negeri 2 Banjar Anyar to determine the practicality of the educational game. The results of the validity test and limited trial were analyzed using the mean formula to determine the average score. The results showed that the material expert score was 4.85 and media expert score was 4.88 which means superfine. As for practicality, the score was 4.5 with superfine criteria. It can be concluded that this educational game can be used as a mathematics learning media on the integers topic for grade VI students of Elementary School.
\end{abstract}

Keywords : Android; Numeral; Education; Game; Mathematics 


\section{PENDAHULUAN}

Pendidikan mengupayakan dalam memanusiakan manusia untuk menuntun segala kekuatan kodrat dan potensinya sebagai seorang individu dan anggota masyarakat untuk mencapai keselamatan dan kebahagiaan hidup yang setinggitingginya. Pendidikan adalah usaha sadar dan terencana untuk mewujudkan susana belajar dan proses pembelajaran agar peserta didik secara aktif mengembangkan potensi dirinya untuk memiliki kekuatan spiritual keagamaan, pengendalian diri, kepribadian,kecerdasan, akhlak mulia, serta keterampilan yang diperlukan dirinya, masyarakat,bangsa dan negara (Sisdiknas pasal 1/2003). Pendidikan menjadi kebutuhan yang primer, karena seiring arus globalisasi yang semakin pesat, peserta didik harus dapat mengikuti perkembangan zaman tersebut. Cara yang paling tepat untuk mengikuti perkembangan zaman adalah dengan belajar. Dari kegiatan belajar, peserta didik diharapkan dapat menyerap informasi sebanyak-banyaknya melalui proses pembelajaran dan dapat menerapkannya dalam kehidupan seharihari.

Tahun 2020 merupakan tahun yang bersejarah bagi orang di seluruh dunia. Semua sektor terdampak oleh sebuah pandemi, yang berawal dari negara Cina. Pandemi tersebuat adalah Covid-19. Sektor pendidikan merupakan salah satu yang terdampak. Pemerintah Indonesia mengambil kebijakan untuk belajar dari rumah bagi semua siswa. Hal tersebut sesuai dengan Surat Edaran Menteri Pendidikan dan Kebudayaan Nomor 4 Tahun 2020 tentang pelaksanaan kebijakan pendidikan dalam masa darurat penyebaran Covid-19.

Berdasarkan surat edaran tersebut, menjadi tantangan tersendiri bagi guru. Guru harus melaksanakan pembelajaran secara daring. Salsabila (2020) mengemukakan bahwa dalam pelaksanaan pembelajaran daring memberikan tantangan tersendiri bagi pelaku pendidikan; seperti pendidik, institusi, dan bahkan memberikan tantangan bagi masyarakat luas seperti para orang tua.

Guru harus menyesuaikan cara mengajarnya dengan situasi dan kondisi belajar dari rumah. Guru mau tidak mau harus bisa menyampaikan materi dengan memanfaatkan teknologi yang ada saat ini. Dalam pelaksanaannya pembelajaran daring tentunya tidak dapat terlepas dari peran teknologi. Teknologi dapat mempermudah segala kebutuhan dalam proses belajar mengajar (Salsabila, 2020). Pembelajaran di sekolah mulai disesuaikan dengan perkembangan teknologi informasi, sehingga terjadi banyak perubahan peningkatan kualitas di dunia pendidikan (Sanaky, 2009). Pemanfaatan teknologi tersebut harus terintegrasi pada semua mata pelajaran, salah satunya matematika. Cornelius (dalam Abdurrahman, 2003) mengemukakan lima alasan perlunya belajar matematika; (1) sarana berpikir yang jelas dan logis bagi peserta didik, (2) sarana untuk memecahkan berbagai masalah kehidupan sehari-hari, (3) sarana mengenal pola-pola hubungan dan generalisasi pengalaman dalam kehidupan siswa, (4) sarana untuk mengembangkan kreativitas siswa, dan (5) sarana untuk meningkatkan kesadaran peserta didik terhadap perkembangan budaya.

Cockroft (dalam Abdurrahman, 2003) mengemukakan bahwa matematika perlu diajarkan kepada siswa karena; (1) selalu digunakan dalam berbagai segi kehidupan, (2) semua bidang studi memerlukan keterampilan pelajaran matematika yang sesuai, (3) sarana komunikasi yang kuat, singkat, dan jelas, (4) dapat dimanfaakan untuk menyajikan informasi dalam berbagai keruangan, (5) memberikan kepuasan terhadap usaha memecahkan masalah yang mendatang pada siswa. Berdasarkan dua pendapat di atas, menunjukkan bahwa mata pelajaran matematika merupakan mata pelajaran yang sangat baik untuk dipelajari. Hal tersebut menjadi mengkhawatirkan karena berdasarkan kuesioner google form 
kepada guru kelas VI di Gugus III Banjar Anyar, diperoleh data $100 \%$ guru menyebutkan bahwa matematika mata pelajaran yang paling sulit untuk di ajarkan saat belajar daring.

Matematika, merupakan mata pelajaran yang bagi kebanyakan siswa mengalami kesulitan dalam memahami pelajarannya. Hidajat (2018) mengemukakan bahwa kebanyakan siswa masih menganggap bahwa matematika merupakan mata pelajaran yang sulit sehingga matematika banyak di hindari. Rulyansyah (2020) juga menyebutkan matematika adalah salah satu jenis mata pelajaran yang menjadi musuh banyak peserta didik dan sedikit peminat. Apalagi di masa pandemi seperti saat ini. Siswa akan sangat kesulitan memahami materi pelajaran yang berdampak pada rendahnya motivasi siswa. Seperti dalam penelitian Cahyani, dkk (2020) bahwa motivasi belajar pada siswa yang mengikuti pembelajaran daring menurun. Cahyani, dkk (2020) mengemukakan bahwa guru dituntut memberikan pengajaran yang baik, menciptakan suasana yang kondusif untuk belajar dan inovatif menggunakan media belajar yang menarik agar siswa dapat memahami materi pelajaran dan tujuan pembelajaran dapat tercapai.

Media adalah sesuatu yang berguna sebagai penyampai pesan. Peranan media pembelajaran dapat merangsang pikiran, perhatian, perasaan, dan minat siswa dalam proses belajar (Sadiman, 2015). Dengan demikian peranan media sangatlah penting dalam kegiatan belajar mengajar. Fakta di lapangan, saat belajar daring guru masih sangat jarang menggunakan media pembelajaran khususnya untuk mata pelajaran matematika. Berdasarkan hasil kuesinoer terhadap guru kelas VI di gugus III Banjar Anyar terkait seberapa sering guru menggunakan media pembelajaran dalam mengajar matematika saat belajar daring, di peroleh data $36,4 \%$ menjawab kadangkadang; 27,3\% jarang; 18,2\% tidak pernah; $9,1 \%$ sering, dan $9,1 \%$ selalu. Dari data tersebut terlihat bahwa guru kelas VI di gugus III Banjar Anyar masih kurang maksimal dalam memanfaatkan media pembelajaran saat mengajar matematika, hanya $9,1 \%$ guru yang selalu menggunakan media pembelajaran. Sangat disayangkan sekali jika guru belum memaksimalkan media dalam pembelajaran. Menurut Arsyad (2014), dua unsur yang amat penting adalah metode mengajar dan media pembelajaran. Menurut Rulyansah (2018), salah satu fungsi utama media pembelajaran adalah sebagai alat bantu mengajar yang turut mempengaruhi iklim, kondisi, dan lingkungan belajar yang ditata dan diciptakan oleh guru.

Masih berdasarkan kuesioner yang diberikan melalui google form, respon guru kelas VI di gugus III Banjar Anyar, terkait bagaimana guru mengajar matematika, guru merasa kesulitan menjelaskan materi matematika kepada siswa melalui pembelajaran daring. Guru juga menyampaikan, pada saat tatap muka saja mereka menjelaskan sampai tiga kali baru siswa paham. Apalagi kalau belajar daring, guru sulit untuk menjelaskannya, walaupun sudah dibimbing dalam menyelesaikan soal di Whatsapp. Rulyansyah, dkk (2019) menyatakan kondisi belajar dengan pemilihan bahan ajar yang kurang tepat sering kali membuat siswa malas untuk mengikuti kegiatan belajar di dalam kelas. Dengan demikian tentu pemilihan bahan ajar sangatlah penting. Masih dalam isi kuesioner, ada guru yang menyuruh siswa untuk mengambil tugas seminggu sekali ke sekolah karena keterbatasan fasilitas HP yang dihadapi. Beberapa guru menuliskan sudah melakukan zoom dengan siswa, namun kurang maksimal. Dalam kuesinoner tersebut guru juga menuliskan bahwa motivasi belajar siswa pada mata pelajaran matematika rendah. Hal tersebut terjadi karena guru kurang memanfaatkan media pembelajaran, sehingga guru sulit untuk menjelaskan materi yang menyebabkan siswa sulit memahami materi dan berdampak pada motivasi belajar yang 
rendah. Hasil kuesioner terhadap guru juga menunjukkan bahwa siswa di gugus III masih kesulitan memahami materi bilangan bulat, dengan rata-rata nilai tes di gugus 68 .

Untuk mengatasi berbagai kendala di atas, maka salah satu yang dapat dilakukan adalah dengan mengembangkan game edukasi sebagai media pembelajaran matematika. Usaha ini di dukung oleh data perolehan kuesioner melalui google formulir di SD Gugus III Banjar Anyar yang menyatakan bahwa 100\% guru setuju untuk adanya pengembangan game edukasi.

Menurut Prensky (dalam Aprilina, 2014) game edukasi merupakan game yang dirancang untuk mengajari manusia tentang subjek tertentu dan mengajari keahlian khusus. Ketika pendidik, orang tua dan pemerintah menyadari kebutuhan psikologis dan keuntungan bermain game dalam pembelajaran, media ini menjadi mainstream dalam pembelajaran. Game edukasi cocok dikembangkan untuk siswa sekolah dasar. Hal ini di dukung oleh penelitian (Ramadhan, dkk., 2019) yang berjudul Pengembangan Game Edukasi Matematika Berbasis Android untuk Sekolah Dasar. Penelitian ini menciptakan game edukasi yang layak digunakan dalam mata pelajaran matematika.

Game edukasi dalam pembelajaran merupakan salah satu alternatif bagi guru untuk meningkatkan motivasi belajar siswa. Menurut penelitian Qomarul (2018) tentang pengembangan media game edukasi, ternyata membawa dampak positif yaitu meningkatnya motivasi belajar siswa. Penelitian Krisbiantoro (2018) juga menghasilkan dampak positif dari pengembangan media game edukasi matematika, yaitu meningkatkan pemahaman siswa sebesar $10 \%$. Hasil penelitian tersebut menjadi penguatan bagi penulis mengembangkan media game edukasi. Karena berdasarkan data kuesioner melalui google formulir, 90\% siswa di kelas VI SD Negeri 2 Banjar Anyar senang bermain game di gawainya. Tentunya menjadi ide menarik untuk mengembangkan game edukasi dalam pembelajaran, terutama di masa belajar dari rumah.

Game edukasi yang dikembangkan adalah sebuah game yang dibuat menggunakan software Smart Apps Creator (SAC) untuk mata pelajaran matematika topik bilangan bulat. Game yang dihasilkan adalah game edukasi yang dapat digunakan oleh smartphone bersistem android.

Harapan dikembangkan media ini agar meningkatkan motivasi belajar dan pemahaman matematika siswa pada topik bilangan bulat. Berpijak pada hal tersebut, maka perlu untuk dilakukan penelitian pengembangan media pembelajaran khususnya pada topik bilangan bulat. Adapun penelitian pengembangan ini berjudul "Pengembangan Media Game Edukasi Berbasis Android pada Topik Bilangan Bulat Kelas VI Sekolah Dasar".

\section{METODE}

Penelitian ini merupakan penelitian pengembangan media pembelajaran yang dikemas dalam media game edukasi. Penelitian ini menggunakan model pengembangan ADDIE (Analysis, Design, Development, Implementation, Evaluation). Model ini dipilih karena memiliki tahap yang sistematis (Tegeh \& Jampel, 2017). Pada tahap analisis, peneliti melakukan beberapa analisis yakni: analisis kebutuhan, analisis kurikulum, dan analisis media yang baik. Tahap desain merupakan tahap yang dilakukan setelah analisis. Tahap ini memiliki tujuan untuk merancang media berdasarkan analisis yang telah dilakukan sebelumnya. Tahap desain merupakan tahap perancangan media yang meliputi pembuatan flowchart, penyusunan materi, soal dan jawaban, pengumpulan background, gambar, tombol, serta musik. Pada tahap development seluruh komponen yang telah dipersiapkan pada tahap desain, dirangkai menjadi satu kesatuan menggunakan software smart app creator (SAC). Seluruh komponen dirangkai menjadi media sesuai dengan flowchart 
Tabel 2. Rekapitulasi Validasi Ahli Media

melalui serangkaian fungsi-fungsi tertentu. Media pembelajaran dibuat dalam format file Application Package File (.apk) dan siap untuk diinstal pada smartphone dengan sistem operasi android. Game yang dihasilkan berjudul "Ayo Selamatkan Bumi"

Data pada penelitian ini diperoleh menggunakan kuesioner yang diisi oleh ahli materi, ahli media, guru, dan siswa.Uji validitas dilakukan oleh ahli media dan ahli materi, sedangkan uji kepraktisan diperoleh dari hasil penilaian siswa terhadap produk. Data dianalisis menggunakan rumus ratarata, kemudian diinterpretasi hasilnya.

\section{HASIL DAN PEMBAHASAN}

Laporan hasil penelitian terdiri dari hasil uji validitas dan uji kepraktisan. Berikut hasil rekapitulasi uji validitas oleh ahli materi yang diperoleh dari dua ahli dan dua praktisi.

Tabel 1. Rekapitulasi Validasi Ahli Materi

\begin{tabular}{llcc}
\hline No & Aspek & $\begin{array}{c}\text { Rata- } \\
\text { rata }\end{array}$ & Keterangan \\
\hline 1 & Isi & 4,86 & Sangat baik \\
2 & Kebahasaan & 4,83 & Sangat baik \\
& Rata-rata & 4,85 & Sangat baik \\
\hline
\end{tabular}

Berdasarkan tabel di atas menunjukkan bahwa dari aspek isi, diperoleh rata-rata 4,86 yang termasuk dalam kategori sangat baik. Pada aspek kebahasaan diperoleh rata-rata 4,83 yang termasuk kategori sangat baik. Secara keseluruhan hasil validasi oleh ahi materi dilihat dari aspek isi dan kebahasaan diperoleh nilai 4,85. Hasil penilaian tersebut masuk dalam rentang $4,01<X \leq 5,01$ dengan kategori sangat baik. Sehingga tingkat validasi media pembelajaran game edukasi "Ayo Selamatkan Bumi" berdasarkan validasi ahli materi masuk ke dalam kategori Sangat Baik.

Selain validitas materi, game edukasi juga diuji validitasnya oleh dua orang ahli media dan dua praktisi. Berikut hasil rekapitulasi uji validitas oleh ahli media yang diperoleh dari dua ahli dan dua praktisi.

\begin{tabular}{cccc}
\hline No & Aspek & $\begin{array}{c}\text { Rata- } \\
\text { rata }\end{array}$ & Keterangan \\
\hline 1 & $\begin{array}{l}\text { Perangkat } \\
\text { lunak }\end{array}$ & 4,85 & Sangat baik \\
2 & $\begin{array}{l}\text { Komunikasi } \\
\text { visual } \\
\text { Rata-rata }\end{array}$ & 4,9 & Sangat baik \\
\hline
\end{tabular}

Berdasarkan tabel di atas menunjukkan bahwa dari aspek perangkat lunak, diperoleh rata-rata 4,85 yang termasuk dalam kategori sangat baik. Pada aspek komunikasi visual diperoleh rata-rata 4,9 yang termasuk kategori sangat baik. Secara keseluruhan hasil validasi oleh ahi media dilihat dari aspek perangkat lunak dan komunikasi visual diperoleh nilai 4,88 . Hasil penilaian tersebut masuk dalam rentang 4,01 $<X \leq 5,01$ dengan kategori sangat baik. Sehingga tingkat validasi media pembelajaran game edukasi "Ayo Selamatkan Bumi" berdasarkan validasi ahli media masuk ke dalam kategori Sangat Baik.

Tahap uji kelompok kecil dilaksanakan pada tanggal 5 Juni 2021 dengan jumlah 9 siswa SD Negeri 2 Banjar Anyar yang beralamat di Banjar Jadi Desa, Banjar Anyar, Kediri, Tabanan. Uji coba ini bertujuan untuk mengetahui kepraktisan media game edukasi. Sebelum media digunakan, siswa diminta untuk menginstall media pada perangkat smartphone. Penyebaran media dilakukan melalui WhatsApp oleh peneliti dengan cara mengirim file .apk kepada masing-masing siswa. Siswa diberi kesempatan untuk mencoba dan mengeksplore game edukasi selama 2 jam. Setelah siswa mencoba game edukasi, mereka diminta respon atau pendapatnya dengan mengisi kuesioner yang telah diberikan melalui google formulir. Rekapitulasi hasil rata-rata penilaian siswa terhadap game edukasi "Ayo Selamatkan Bumi" dapat dilihat pada tabel berikut. 
Tabel 3. Rekapitulasi Uji Kepraktisan Media

\begin{tabular}{llcl}
\hline No & \multicolumn{1}{c}{ Aspek } & $\begin{array}{c}\text { Rata- } \\
\text { rata }\end{array}$ & Keterangan \\
\hline 1 & Operasional & 4,3 & Sangat baik \\
2 & $\begin{array}{l}\text { Desain } \\
\text { pembelajaran }\end{array}$ & 4,6 & Sangat baik \\
3 & $\begin{array}{l}\text { Komunikasi } \\
\text { visual } \\
\text { Rata-rata }\end{array}$ & 4,5 & Sangat baik \\
& 4,5 & Sangat baik \\
\hline
\end{tabular}

Berdasarkan tabel 3, penilaian siswa ditinjau dari aspek operasional memperoleh skor rata-rata 4,3. Hal ini menunjukkan tingkat kerpraktisan game edukasi pada aspek operasional mendapatkan kualifikasi sangat baik. Pada aspek desain pembelajaran, penilaian siswa menunjukkan rata-rata 4,6 yang termasuk dalam kualifikasi sangat baik. Pada aspek komunikasi visual, penilaian siswa juga ada pada kualifikasi sangat baik dengan rerata skor 4,5. Secara keseluruhan kepraktisan game edukasi "Ayo Selamatkan Bumi" ada pada kualifikasi sangat baik, dengan ratarata 4,5 .

Penelitian pengembangan ini menghasilkan media game edukasi berbasis android pada topik bilangan bulat kelas VI Sekolah Dasar yang valid dan praktis. Pengembangan media game edukasi berdasarkan hasil analisis kebutuhan pengguna yang diperoleh dari kuesioner menggunakan google form pada guru kelas VI di Gugus III Banjar Anyar. Sehingga penelitian ini berdasarkan keadaan yang sesuai di lapangan. Semua guru menyebutkan bahwa mata pelajaran matematika paling sulit dibelajarkan saat belajar daring.

Materi matematika yang dibelajarkan melalui media game edukasi pada pengembangan media ini adalah bilangan bulat. Hal ini sesuai dengan hasil isian kuesioner yang di isi oleh guru, bahwa topik bilangan bulat mendapatkan nilai rendah pada saat belajar daring. Guru menyampaikan kesulitan untuk menjelaskan materi. Guru juga hanya memanfaatkan media WhatsApp untuk memberikan tugas kepada siswa. Ada juga yang memanfaatkan zoom, namun belum maksimal. Dengan demikian, guru belum menggunakan media belajar dengan baik.

Game edukasi yang dikembangkan ini merupakan sesuatu hal yang baru, karena terdapat soal HOTS di dalamnya. Terdapat tiga menu soal HOTS yang berbeda. Game juga dilatarbelakangi cerita yang menarik, supaya siswa dapat tertantang menyelesaikannya. Siswa harus melawan musuh dengan tiga level berbeda. Setiap level berisi pertanyaan terkait dengan materi topik bilangan bulat. Siswa akan terbiasa berlatih mengerjakan soal bilangan bulat dan mengulangnya jika jawaban belum benar semua.

Tampilan game edukasi dapat dilihat pada gambar 1 sampai 8 .

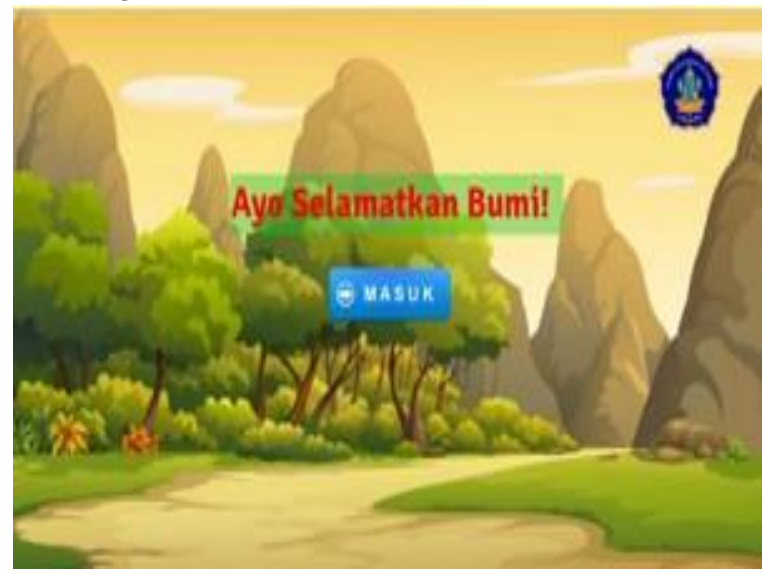

Gambar 1. Tampilan awal game

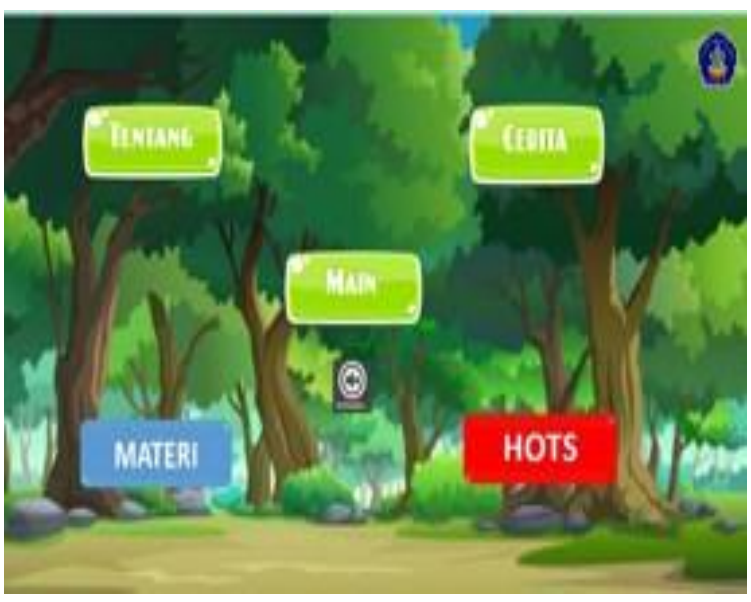

Gambar 2. Tampilan menu game 


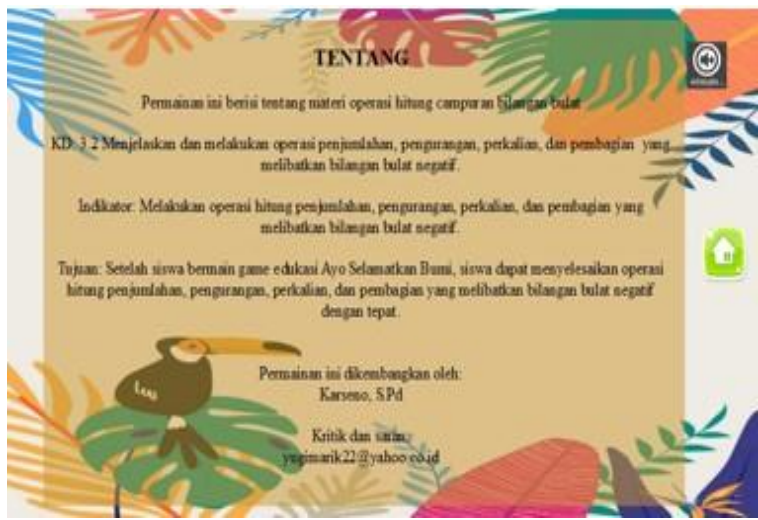

Gambar 3. Tampilan menu tentang

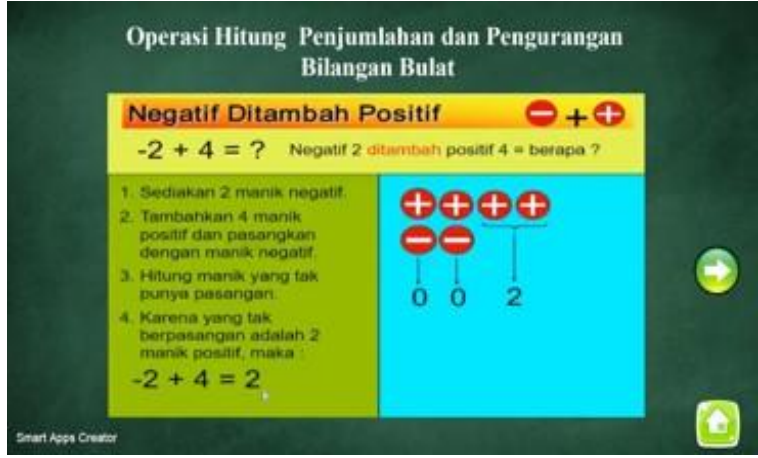

Gambar 4. Tampilan menu materi

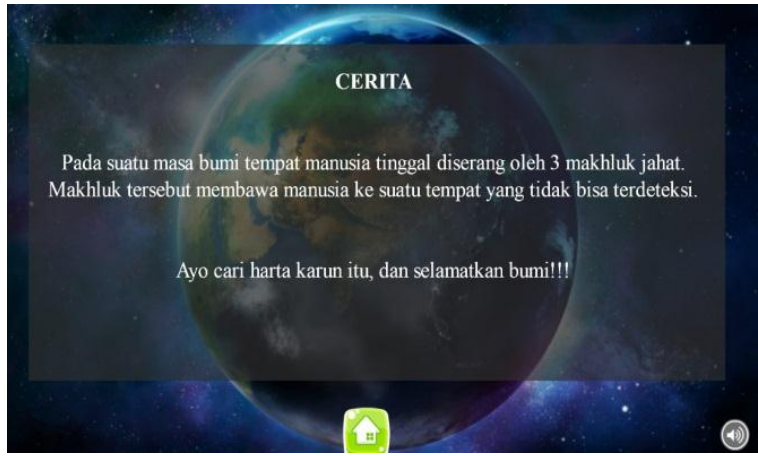

Gambar 5. Tampilan menu cerita

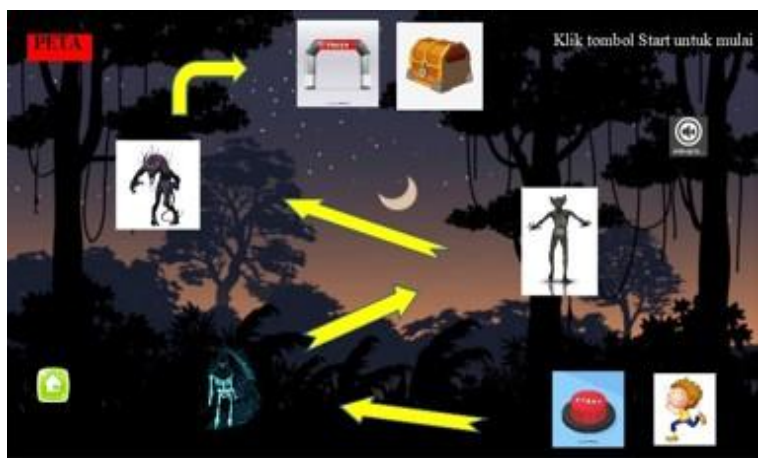

Gambar 6. Tampilan menu main

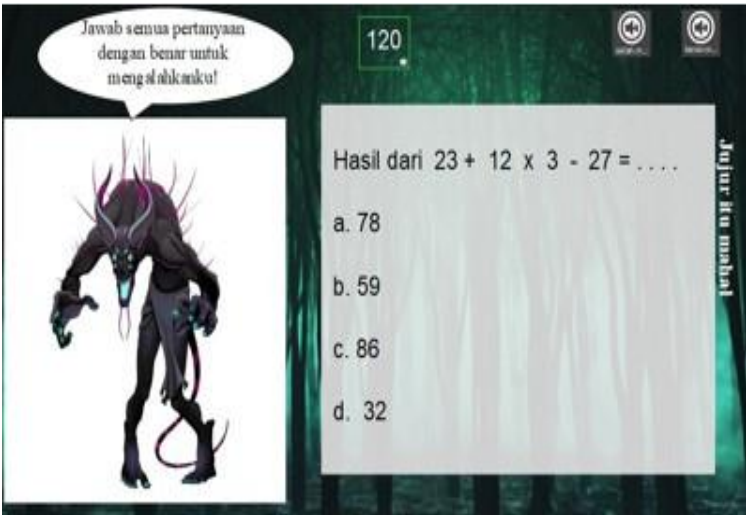

Gambar 7. Tampilan soal di game

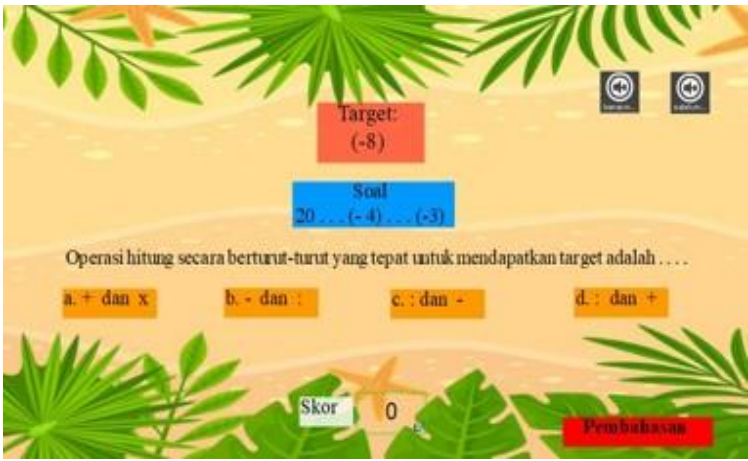

Gambar 8. Tampilan soal di game

Penggunaan media game edukasi sejalan dengan teori Throndike. Menurut Firliani, dkk (2019) pada teori belajar Thorndike lebih menekankan siswa untuk banyak berlatih dan mencoba. Teori ini asejalan dengan game edukasi yang dikembangkan, dimana siswa harus berlatih dan mencoba. Apabila siswa melakukan kesalahan, maka siswa harus mengulang kembali sampai benar. Dengan demikian pemahaman siswa pada konsep matematika akan tersimpan di dalam otak karena siswa melakukannya berulang-ulang sampai menemukan nilai kebenaran sendiri.

Karakteristik peserta didik juga dipertimbangkan dalam pengembangan media game edukasi. Meriyati (2015) menyebutkan anak usia SD senang bermain, senang bergerak, senang bekerja dalam kelompok dan senang merasakan atau melakukan sesuatu secara langsung. Melalui game edukasi ini siswa diajak bermain menyelesaikan misi, namun dibalik 
itu siswa sedang belajar mengenai topik bilangan bulat.

Pengembangan game edukasi ini menggunakan model ADDIE. Model ADDIE terdiri atas analisis (Analyze), desain (Design), pengembangan (Development), implementasi (Implementation) dan evaluasi (Evaluation). Menurut Tegeh, dkk (2014) model ADDIE ini memiliki lima langkah atau tahapan yang mudah dipahami dan diimplementasikan untuk mengembangkan produk pengembangan seperti buku ajar, modul pembelajaran, video pembelajaran, multimedia, dan lain sebagainya.

Pada tahap analisis; peneliti melakukan analisis kebutuhan, analisis kurikulum, dan analisis karakteristik siswa. Peneliti melakukan analisis tersebut dengan tujuan memperoleh informasi awal yang baik sebelum melanjutkan pada tahapan berikutnya. Pada tahap desain; peneliti membuat flowchart, menyusun materi, soal, jawaban, mencari background, gambar, dan mencari musik. Keseluruhan file yang digunakan menggunakan sumber internet dengan mode bebas hak cipta. Peneliti mencari file gambar di situs https://www.freepik.com/ dan untuk musik, dengan mendownload di Youtube kemudian di konversi ke format .mp3.

Tahap pengembangan, pada tahap ini peneliti membuat media menggunakan software smart app creator (SAC). File yang disediakan pada tahap desain dimasukakan kedalam software SAC. Dengan fungsifungsi tertentu yang ada pada software SAC, file akhirnya adalah game edukasi dengan format .apk supaya dapat di install pada smartphone bersistem android. Langkah selanjutnya adalah uji validitas oleh 2 ahli dan 2 praktisi guru.

Media game edukasi ini sudah melewati uji validitas oleh ahli materi dan ahli media. Uji validitas materi dilakukan oleh dua dosen dan dua praktisi dengan perolehan data pada aspek isi skor 4,86 dan aspek kebahasaan 4,83 sehingga rerata oleh ahli materi adalah 4,85. Dengan demikian kualifikasi validitas oleh ahli materi pada kategori sangat baik.

Uji validitas media juga dilakukan oleh dua dosen dan dua praktisi, diperoleh data pada aspek perangkat lunak memperoleh skor 4,85 dan pada aspek komunikasi visual 4,9. Rerata dari dua aspek tersebut adalah 4,88. Skor rerata tersebut menunjukkan kualifikasi validitas media game edukasi oleh ahli media pada kategori sangat baik.

Media game edukasi juga mendapatkan masukan/saran dari para ahli. Revisi dilakukan pada penataan warna di menu materi, memperjelas alur game, dan suara supaya tidak mengganggu.

Uji coba kelompok kecil dilakukan peneliti untuk mencari tingkat kepraktisan media game edukasi. Tahap uji kelompok kecil dilaksanakan pada tanggal 5 Juni 2021 dengan jumlah 9 siswa SD Negeri 2 Banjar Anyar yang beralamat di Banjar Jadi Desa, Banjar Anyar, Kediri, Tabanan. Uji coba dilaksanakan secara daring dengan mengirimkan file apk melalui WhatsApp, kemudian siswa diberi kesempatan memainkan game selama 2 jam. Setelah waktu habis, siswa mengisi kuesioner yang diberikan melalui google formulir. Berdasarkan respon siswa, hasil dari uji coba terbatas ini diperoleh data rerata skor pada aspek operasinal 4.3, aspek desain pembelajaran 4.6, dan aspek komunikasi visual 4.5. Rerata keseluruhan aspek yang diperoleh dari respon siswa adalah 4.5, yang berarti bahwa tingkat kepraktisan game edukasi masuk kategori sangat baik.

Berdasarkan uji validitas dan kepraktisan di atas, maka media game edukasi berbasis android pada topik bilangan bulat untuk siswa kelas VI SD dinyatakan valid dan praktis.

Setelah mendapatkan validasi, revisi, uji coba terbatas; maka diperoleh prototipe game edukasi dengan nama Ayo Selamatkan Bumi; terdapat 5 menu utama yaitu "tentang" (berisi informasi KD, indikator, tujuan, dan identitas pembuat), "cerita" (berisi kisah singkat Ayo Selamatkan Bumi), "main" (berisi peta dan permainan 
dengan 3 level, dengan jumlah total 24 soal), higher order thingking skills/HOTS (berisi tentang soal dengan menguji kemampuan berpikir tingkat tinggi, dengan jumlah total soal 12), dan "materi" (berisi contoh soal dan pembahasannya). File game edukasi berformat .apk dan harus dimainkan dengan smartphone bersistem android.

Game edukasi "Ayo Selamatkan Bumi" memiliki kelebihan dan kelemahan. Kelebihannya adalah dapat digunakan orang banyak, mudah digunakan, ukuran file kecil, ramah lingkungan, tampilan menarik, bisa dimainkan berulang, dan bisa dimainkan kapanpun. Game edukasi juga di dukung oleh penelitian terdahulu. Luthfya (2020) dalam penelitiannya terkait game edukasi menghasilkan game edukasi yang valid dan praktis untuk menambah minat siswa dalam belajar matematika dan dapat memfasilitasi pemahaman konsep siswa. Amanda (2019) mengembangkan game edukasi berbasis android yang layak setelah melalui serangkaian uji media dan uji materi. Uji media mendapat $86,6 \%$ dan uji materi sebesar 100\%. Putri (2019) mengembangkan edugame operasi hitung matematika untuk anak Sekolah Dasar (SD) berbasis android, menyatakan bahwa dari hasil uji buildbox menyatakan bahwa aplikasi edugame berjalan dengan baik, serta kuesioner menunjukkan bahwa aplikasi ini dapat membantu proses pembelajaran menjadi lebih menarik. Berdasarkan pengembangan terdahulu yang juga menghasilkan game edukasi, menjadi suatu penguatan bahwa game edukasi layak dikembangkan dan bermanfaat bagi pesera didik.

Kelemahan game edukasi ini adalah soal yang tidak diacak dan belum bisa di kirim secara online skornya, selain itu juga peneliti belum mampu membuat video animasi sebagai latar belakang cerita dalam game edukasi. Keterbatasan dalam penelitian ini adalah penelitian hanya sampai pada tahap pengembangan yaitu pada tahap uji validitas dan kepraktisan saja. Tahap implementasi tidak dapat dilakukan karena keterbatasan tenaga, sumber daya dan biaya. Produk game edukasi yang dikembangkan belum diuji cobakan dalam skala besar dan juga keefektifannya.

\section{PENUTUP}

Berdasarkan hasil penelitian dan pembahasan yang telah dikemukakan sebelumnya, maka dapat disimpulkan beberapa hal sebagai berikut: (1) media game edukasi berbasis android pada topik bilangan bulat kelas VI di Sekolah Dasar memiliki validitas sangat baik. Dengan rerata skor ahli materi 4,85 dan ahli media 4,88; (2) media game edukasi berbasis android pada topik bilangan bulat kelas VI di Sekolah Dasar memiliki kepraktisan sangat baik. Dengan rerata skor 4,5.

Berdasarkan hasil penelitian ini, dapat disarankan kepada guru, harus mempersiapkan RPP yang baik lengkap dengan langkah pembelajaran yang jelas, dan membuat media pembelajaran yang inovatif. Guru juga disarankan membuat kesepakatan bersama terkait dengan waktu bermain menggunakan game edukasi. Kepada siswa, disarankan agar memanfaatkan dengan bijak smartphone yang mereka punya. Tidak hanya untuk bermain game online, tetapi juga belajar menggunakan game edukasi. Kepada pihak sekolah, sebaiknya mendukung kegiatan penelitian yang dilakukan di sekolah, baik yang dilakukan oleh guru setempat maupun oleh peneliti dari luar. Hal ini dapat memeberikan dampak positif khususnya dalam upaya peningkatan kualitas pembelajaran.

\section{DAFTAR PUSTAKA}

Abdurrahman, Mulyono. 2003. Pendidikan Bagi Anak Berkesulitan Belajar. Jakarta: Rineka Cipta.

Amanda, Desyka Ayu. 2019. Pengembangan Game Edukasi pada Mata Pelajaran Matematika Materi Bangun Datar Berbasis Android Di 
SDN 1 Jepun. JOEICT (Jurnal of Education and Information Communication Technology) Volume 03, Nomor 02, Agustus 2019: 160 168.

Aprilina, Cheri dan Hanif Al Fatta. 2014. Perancangan Game Edukasi "Cooking For Child". Jurnal. Jurnal IImiah DASI Vol 15 No.04.

Arsyad, Azhar. 2014. Media Pembelajaran. Depok: PT Rajagrafindo Persada.

Cahyani, dkk. 2020. Motivasi Belajar Siswa SMA pada Pembelajaran Daring di Masa Pandemi Covid-19. Jurnal. Jurnal Pendidikan Islam. Volume 3 no.012020 p.123-140.

Firliani, dkk. 2019. Teori Throndike dan Implikasinya dalam Pembelajaran Matematika. Semnas Pendidikan, FKIP UNMA 2019.

Hidajat, Djatmiko, dkk. 2018. Anasilis Kesulitan dalam Penyelesaian Permasalahan Ruang Dimensi Dua. Jurnal. Jurnal Pendidikan Matematika IA IN Kudus. Vol 1 No 1.

Krisbiantoro, Dwi. 2018. Game Matematika sebagai Upaya Peningkatan Pemahaman Matematika Siswa Sekolah Dasar. Jurnal. Jurnal Telematika Vol 10 No. 2 Agustus 2018.

Luthfya, Ulya Za'im. 2020. Pengembangan Game Edukasi "Beruang Pintar (Belajar Bangun Ruang Pintar)" untuk Memfasilitasi Pemahaman Konsep. UNION: Jurnal Pendidikan Matematika Volume 8 No 2 Tahun 2020

Meriyati. 2015. Memahami Karakteristik Anak Didik. Lampung: Fakta Press.

Putri, Devi Afriyantari Puspa. 2019. Edugame Operasi Hitung Matematika untuk Anak Sekolah Dasar (SD) Berbasis Android. Jurnal PROtek Volume 06. No 2, September 2019.
Qomarul, Rohman. 2018. Pengembangan Media Pembelajaran Game Edukasi Fisika untuk Meningkatkan Motivasi dan Prestasi Belajar Siswa pada Materi Belajar Siswa. Jurnal. JPPF, Vol. 8 No. 2 Tahun 2018.

Ramadhan, Tarmidzi, dkk. 2019. Pengembangan Game Edukasi Matematika berbasis Android untuk Sekolah Dasar. Jurnal IImiah Edutic, Volume 5, Nomor 2.

Rulyansah, Afib. 2018. Pengembangan Modul Berbasis Kecakapan Hidup pada Pelajaran Matematika Sekolah Dasar. Jurnal. Must: Journal of Mathematic Education, Scinece, and Technology Vol 3 No 2.

Sadiman, Arief, dkk. 2015. Media pendidikan. Jakarta: Raja Grafindo Persada.

Salsabila, Unik Hanifah, dkk. 2020. Peran Teknologi dalam Pembelajaran di Masa Pandemi Covid-19. Jurnal. AlMutharahah: Jurnal Penelitian dan Kajian Sosial Keagamaan. Vol. 17 No. 2. Juli-Desember 2020.

Sanaky, Hujair. 2009. Media Pembelajaran. Yogyakarta: Sifiria Insania Press.

Tegeh, I Made dan I Nyoman Jampel. 2017. Metode Penelitian Pengembangan. Singaraja: Universitas Pendidikan Ganesha. 